\title{
Disaster preparedness and response in Brazil in the face of the COVID-19 pandemic
}

\author{
Karina Furtado Rodrigues ${ }^{1}$ \\ Mariana Montez Carpes ${ }^{1}$ \\ Carolina Gomes Raffagnato ${ }^{1}$ \\ ${ }^{1}$ Escola de Comando e Estado-Maior do Exército / Post-Graduate Program in Military Sciences (PPGCM) at the \\ Meira Mattos Institute (IMM), Rio de Janeiro / RJ - Brazil
}

This article aims to understand how the National System of Protection and Civil Defense functions in response to COVID-19, with emphasis on the work of the Ministry of Health, which is the body responsible for tackling health threats. Three specific objectives were used: the first characterizes COVID-19 as a public health event that can represent a disaster; the second situates the concepts of preparedness and response in the disaster governance literature; the third identifies the jurisprudence and the functioning of disaster management in Brazil. The findings show that, despite the political decision-making tensions, the Brazilian professional bureaucracy managed to guarantee the activation of the disaster governance system related to the preparation and response phases. However, its activation was not enough to allay the crisis. The severity of the pandemic exposed flaws in the phases of disaster prevention and mitigation, as well as the lack of coordinated government response.

Keywords: COVID-19; Disaster Management; Brazilian National Civil Protection and Defense System; Public Health.

\section{Preparação e resposta a desastres do Brasil na pandemia da COVID-19}

Como a crise em saúde pública causada pela pandemia da COVID-19 ajuda a compreender o funcionamento do Sistema Nacional de Proteção e Defesa Civil (SINPDEC) nas fases de preparação e resposta a desastres em saúde no Brasil? A resposta a essa pergunta se dará por meio do seguinte objetivo geral: compreender o funcionamento do SINPDEC no enfrentamento à COVID-19, com ênfase na atuação do Ministério da Saúde (MS), órgão gestor de combate às ameaças em saúde. Para tanto, três objetivos específicos serão explorados: caracterizar a (doença) COVID-19 como evento em saúde pública com potencial causador de desastre, situar os conceitos de preparação e resposta na literatura de governança de desastres e identificar previsões legais e funcionamento da gestão de desastres no Brasil. A despeito das tensões decisórias no âmbito político, a burocracia profissional brasileira conseguiu garantir a ativação do sistema de governança de desastres relativa às fases de preparação e resposta. Contudo, sua ativação não foi suficiente para aplacar a crise, cujo agravamento expõe falhas nas fases de prevenção e mitigação de desastres, bem como a falta de uma resposta ao desastre em âmbito federativo.

Palavras-chave: COVID-19; gestão de desastres; Sistema Nacional de Proteção e Defesa Civil; saúde pública.

\section{Preparación y respuesta a desastres de Brasil en la pandemia de COVID-19}

¿Cómo la crisis de salud pública causada por la pandemia de COVID-19 ayuda a comprender el funcionamiento del Sistema Nacional de Protección y Defensa Civil (SINPDEC) en las fases de preparación y respuesta a desastres de salud en Brasil? La respuesta a esta pregunta se dará mediante el siguiente objetivo general de investigación: comprender el funcionamiento del SINPDEC en el afrontamiento a la COVID-19, con énfasis en el trabajo del Ministerio de Salud, organismo gestor del combate contra las amenazas a la salud. Con este fin, se explorarán tres objetivos específicos: caracterizar la COVID-19 como un evento de salud pública con el potencial de causar un desastre; situar los conceptos de preparación y respuesta en la literatura sobre gestión de desastres; e identificar las predicciones legales y el funcionamiento de la gestión de desastres en Brasil. Se argumenta que, a pesar de las tensiones políticas en la toma de decisiones, la burocracia profesional brasileña logró garantizar la activación del sistema de gestión de desastres relacionado con las fases de preparación y respuesta. Sin embargo, su activación no fue suficiente para aplacar la crisis, cuyo empeoramiento expone fallas en las fases de prevención y mitigación de desastres, así como la falta -e importancia- de una respuesta al desastre en ámbito federativo.

Palabras clave: COVID-19; gestión de desastres; Sistema Nacional de Protección Civil; salud pública. 


\section{INTRODUCTION}

In mid-November 2019, rumors of a "mysterious pneumonia" surfaced in Wuhan, China. On December 31, the World Health Organization (WHO) was notified of the disease (Praia Vermelha Military Observatory [OMPV], 2020a), and in the first days of January 2020, several researchers around the world had completed the RNA sequencing of the virus. There was no doubt: a new virus of the coronavirus family, SARS-CoV-2, and the respiratory disease caused by it, COVID-19, had been discovered.

Subsequently, on January 27, 2020, three events prompted WHO to change the COVID-19 global risk from moderate to high. First, the confirmation that the disease could be transmitted human to human in a sustainable manner (OMPV, 2020c). Second, on January 11, the first death by COVID-19 in China was recorded (OMPV, 2020b). Finally, the disease arrive in other countries (OMPV, 2020c). On January 30, WHO declared a Public Health Emergency of International Importance (ESPII) (OMPV, 2020d).

On March 11, the organization updated the status of COVID-19 to a pandemic (OMPV, 2020e), which meant that the virus was circulating in all continents. The most important event, however, was the declaration of the ESPII in January; it conveyed the message of the risk posed by the disease on the world, indicating the need for coordinated actions to combat it. In other words, the WHO declaration was a call to States to prepare their national mechanisms for managing and responding to this biological disaster.

Although the COVID-19 pandemic was not the first in this century ${ }^{1}$, and is still in an upward contamination curve in some countries, it has generated unprecedented impacts on society. It is not possible to determine the consequences that it will have in the medium and long terms, but in the short term, it is clear that the main challenge has been the management of the disaster (see section 3 ).

Given this scenario, the question this article poses is how the public health crisis caused by the COVID-19 pandemic can help to understand the work of the National Civil Protection and Defense System (SINPDEC) in the preparedness and response phases of health disasters in Brazil. The general objective of this study is to understand how the system worked in response to COVID-19, with emphasis on the work of the Ministry of Health (MS), the managing body in the fight against health threats.

The operationalization of this study will be undertaken by characterizing COVID-19 as a public health threat with potential to cause disaster; by verifying the concepts of preparedness and response in the disaster governance literature; and by identifying the legal provisions and the work of disaster management in Brazil. The time frame of this article begins with the first reports of atypical pneumonia in China and ends with the dismissal of the now former Minister of Health, Luiz Henrique Mandetta.

Despite the political decision-making tensions, the Brazilian professional bureaucracy was able to guarantee the activation of the system with regard to the preparedness and response phases

\footnotetext{
${ }^{1}$ In 2009, the world experienced the Influenza A H1N1/09 pandemic, a variant of the already known Influenza A H1N1 virus. Although new, the flu caused by this virus had no implications comparable to those of the current pandemic. In the case of H1N1, because it was a flu virus, treatment protocols already known were effective. In addition, the morbidity rate, as well as the recovery time of those infected with H1N1, were lower than that of SARS-CoV-2.
} 
provided in the SINPDEC. For the sake of the argument presented in this article, the assumption is that the country has a disaster governance structure that includes measures ranging from prevention to recovery of the affected areas, as described in the National Civil Protection and Defense Policy (PNPDEC). Considering that Brazil is a member of both the United Nations (UN) and the World Health Organization (WHO), it is the country's responsibility to internalize, by way of appropriate legal frameworks, the agreed international commitments. For instance, (a) the WHO recommendations of 2005 regarding the need for countries to strengthen, or establish, their pandemic preparedness and response mechanisms (see section 3); and (b) the International Health Regulations (RSI) approved at the WHO 58th World Health Assembly (see section 4).

Health is not one of Brazil's strategic areas, and consequently, the country's health structure is fragile, jeopardizing its ability to react to the prevention and mitigation phases, and to the response and recovery phases of the disaster cycle ${ }^{2}$. This became evident upon the discontinuity of leadership in the Ministry of Health (MS) and in the political tension that marks the management of the crisis. Furthermore, the pressure to minimize the gravity of the crisis has not gone unfelt by the bureaucratic isolation of specialized health and disaster structures in Brazil.

This article is divided in seven parts, including this Introduction. The second part presents the chosen methodological tool: process tracing. The third introduces the theoretical-conceptual framework of the governance literature and the disaster management cycle. The fourth deals with the disaster governance structure of the Brazilian health system, while the fifth discusses the activation of the system to face the pandemic in Brazil. The sixth returns to the methodological choices and the theoretical-conceptual framework, inferring the challenges in the work of the SINPDEC, based on the chronological sequence in the fifth section. Finally, in the conclusions, the findings of this article are discussed and suggestions for a follow up to this research are presented, emphasizing the assessment of the decisions made.

\section{METHODOLOGY}

In this article, the method chosen to operationalize the research and give meaning to its findings was process tracing. The most widespread classification of process tracing divides this methodology between testing and theory development (Checkel, 2008; George \& Bennett, 2005); some authors consider the historical narrative to be a third type of process tracing (George \& Bennett, 2005; Mahoney, 2015; Tannenwald, 2007) and others propose the explanation of results as the third variant of the method (Beach \& Pedersen 2013).

Nevertheless, these classifications leave out a simpler, but fundamental type of process tracing: the descriptive inference, whose definition comes close to the historical narrative, but cannot be considered a synonym. The reason for this is that tests, theoretical development and historical narratives focus on the causative dimension of the phenomena to be studied. Thus, descriptive inferences would be an earlier step, in which one seeks to select and make sense of the phenomena before analyzing them.

\footnotetext{
2 In 2008, the Productive Development Policy (PDP) was launched, which established five strategic areas, including health. However, since then, what has been verified is the absence of the conversion of the PDP guidelines into public policies to promote this area.
} 
With this methodological approach, the focus here is exclusively on the process tracing of descriptive inferences in order to understand the limitations of the handling of COVID-19 in Brazil, regardless of the adequate operation of the National Civil Protection and Defense System (SINPDEC), and the consequent triggering of the pandemic preparedness and response phases. Despite the closeness of the historical narrative to the descriptive inference, the latter allows the study of empirical cases of the present time (Bennett, 2015), yet it is not committed to demonstrating the causal nexus that link initial conditions to results. In the descriptive inferences, the method uses the surgical study of a previously defined chronological sequence of events, looking for evidence that supports or rejects the arguments defended by the research (Collier, 2011). Thus, the descriptive inferences derived from process tracing are not intended to be generalizable. They are, nonetheless, a useful variant of the method for single case studies, such as the one undertaken here.

Bennett (2015) and Collier (2011) argue in favor of the legitimacy of this type of study, despite recognizing that the notoriety of process tracing came from its ability to generate causal inferences (George \& Bennett, 2010; Mahoney, 2015). However, according to Bennett (2015), descriptive inferences are a precondition - although often neglected - for causal inferences, which depend on the previous domain of the phenomenon to be analyzed. This domain derives from the vertical and systematic knowledge of the empirical case.

To clarify the differentiation and codependency between the forms of process tracing, it is necessary to characterize the causal inference. As Checkel (2006) explains well, process tracing, in its analytical form, seeks to identify the causal mechanisms of explanatory variables. This is possible because, as the name reveals, it is a process mapping methodology. Beach and Pedersen (2013) disagree with Checkel's proposition - as do George and Bennett - on the relationship between process tracing and the process as an empirical part of a historical continuum, defending that process tracing allows an analytical exercise focused on specific moments, enabling the visualization of the causal mechanism of interest (Beach \& Pedersen, 2013; Beach, 2016).

Given that the present article constitutes the publication of the first phase of a research agenda on disaster governance in Brazil, the focus being on the description of the events is justifiable, concomitantly with the identification of the obstacles, which will be analyzed in later phases of the research. It is also important to note the relevance of this type of process tracing beyond the academic debate on testing or generating hypotheses.

Bennett $(2015$, p. 4$)$ defends the application of process tracing as a methodology that helps decision makers to "make mid-course corrections with the help of process tracing, updating expected outcomes in light of new evidence on whether policies are working as planned". His observation sheds light on two valued aspects of the present research. The first deals with the characteristics of the study of public policies that assume the need to make fine adjustments to decisions while they are taking place. The second is in respect to the methodological aspect, since process tracing is not a closed model and allows the researcher to extrapolate the established chronological profile, shedding light on moments of decision making prior to the observed phenomenon whose implications materialize in the period under observation. Specifically in the case of the present research, the (non) choices made by Brazil still in the early years of the 21 st century, will demonstrate the impact on the country's ability to prepare for (and respond to) a disaster like the current one. 
Finally, it is worth making some further observations regarding the choice of the method and the way it enables the operationalization of this research. As George and Bennett (2005) have well observed, process tracing is a methodology that considers the complexity of the social phenomenon. Thus, the method works with the concept of equifinality, i.e., it assumes that the resulting observations of social phenomena can originate from different combinations of initial causes, being, therefore, skeptical of the existence of singular causes capable of giving meaning to social complexity.

With this in mind, and returning to the debate presented in this section, this article offers a proximity to the discussion on disaster management in Brazil, focusing on the preparedness and response phases to COVID-19, without, however, denying that part of the current difficulties stem from past decisions that have undermined the prevention and mitigation phases.

With regard to data collection, the article used news clippings organized by the Military Observatory of Praia Vermelha (OMPV, 2020). The collection was made based on the review of publications from the main news agencies in the world, mostly free of charge, and from the largest newspapers in Brazil ${ }^{3}$. In addition, the article is supported by secondary literature on disaster governance, the documentation that structures governance and international documents on health and disasters.

\section{THEORETICAL-CONCEPTUAL FRAMEWORK}

Pandemics such as COVID-19 can be characterized as disasters, i.e., atypical crises of large magnitude, which provoke an exhaustion of the responding agencies' individual capabilities in the country where they occur (Kiruthu, 2012). Prognosis of this type of disaster have long existed in literature, and since the beginning of the debate the question has always been less about whether and more about when a pandemic ${ }^{4}$ would occur (Enserink, 2004). This has been evident since 2005 when, because of the consequences of the Severe Acute Respiratory Syndrome (SARS-CoV-2), WHO put forth a series of recommendations to help countries prepare for such an event.

The WHO Executive Secretariat's report, released that same year, entitled 'Strengthening pandemic influenza preparedness and response', already affirmed that this event (SARS-CoV-2) was the closest to a pandemic ${ }^{5}$ that the world had seen since $1968^{6}$. In this context, and based on the logic of strategic thinking, it was pressing to strengthen (or develop) national plans and structures for a disaster management cycle. This included ensuring the capacity to produce vaccines, guaranteeing the production of supplies and assuring the development of human capital.

More recently, documents setting out general priorities for disaster preparedness, control and risk reduction - which include pandemic disasters - have also been developed. This is the case of the Marco Sendai for Disaster Risk Reduction 2015-2030, written by the United Nations Office for Disaster Risk Reduction (UNDRR) ${ }^{7}$ (Etinay, Egbu, \& Murray, 2018). In this document, the Office establishes

\footnotetext{
${ }^{3}$ AFP, EFE, Reuters, BBC, G1, Deutsche Welle, El País and CNN.

${ }^{4}$ In the Brazilian case, see art. 144 of the 1988 Brazilian Constitution.

${ }^{5}$ Endemic refers to diseases with a continuous presence in a given geographical area - for example, malaria in tropical forest regions. Outbreaks relate to an unusual increase in the number of cases of a disease in a given period and area. Epidemics, on the other hand, are characterized by the affliction of a large population by a disease, reaching a vast geographical area. Finally, pandemics characterize the outbreak of the epidemic beyond national borders, with its occurrence recorded on several continents.

${ }^{6}$ The date refers to the bird flu epidemic, dubbed the Hong Kong flu.

${ }^{7}$ UNDRR used to be UNISDR.
} 
four priority actions for States: understanding disaster risks, strengthening disaster risks governance to manage those risks, investing in building resilience for risk reduction and increasing disaster preparedness; enabling an effective response and swift recovery, rehabilitation and reconstruction phases (UNDRR, 2015).

The priority actions suggested by the UNDRR may take different forms depending on the type of disaster that has occurred. WHO distinguishes them into four types: natural, technological, biological and societal. Examples of natural disasters are earthquakes, tsunamis, cyclones, droughts and floods. The technological ones are different from the first because they result from human error, such as the one that led to the nuclear accident in Fukushima, the collapsing of buildings and other structures, plane crashes and chemical spills. Examples of biological disasters are epidemics, infestations and pests. Finally, societal disasters involve conflicts or intentional acts such as terrorism and cyber attacks, among others (Do, 2019; WHO, 2011; Quarantelli, Lagadec, \& Boin, 2007).

According to this classification, the COVID-19 pandemic is a biological disaster. However, it would be an oversight not to add that, although a disease may appear to be a natural phenomenon, human practices - ranging from deforestation to the indiscriminate consumption of game meat - have generated imbalance in the ecosystem, increasing the likelihood of new zoonotic ${ }^{8}$ diseases. In addition to this, technological advancement has greatly increased the circulation of people around the world. Furthermore, there is an incidence of a societal character to the disaster in many countries, given that large portions of the population do not have access to basic sanitation and live in precarious structures that make isolation impossible, impelling them to break the isolation to maintain their livelihood (Lima, 2014).

Thus, the COVID-19 pandemic could be defined as a biological disaster with technological and societal elements actively affecting its dissemination. This type of disaster can be called a "trans-system social rupture" (terminology suggested by Quarantelli et al., 2007), which, due to its scale, impact and information and misinformation overflow, increase the probability of social amplification of the tragedy. In other words, the perception of the crisis can be distorted given the psychological, social, institutional and cultural characteristics of the affected area.

Faced with such a complex problem, disaster governance ${ }^{9}$ and its effect on the management cycle of disasters must be considered. In this type of governance, the assumption is that "only variety can destroy variety" (Kooiman, 1999, p. 74). This implies that the problems have multiple origins, which means that only the joint and coordinated action of various solutions and institutions can be capable of placating the problem, not just in terms of health, but also in the impacts that the pandemic brings to the economic, social and environmental dimensions of this event (Börzel, 2011; Zurita, Cook, Harms, \& March, 2015).

Because each type of disaster affects a different range of specialties, the initial action of a specific area often prevails. In the case of the COVID-19 pandemic, as it is fundamentally a biological disaster,

\footnotetext{
${ }^{8}$ Zoonoses occur through spillover (or jumps) between species and occur when viruses or bacteria present in host animals "jump" from them to humans, becoming pathogens that cause new diseases (Dhiman \& Tiwari, 2018).

${ }^{9}$ In this article, we adopt the concept of governance discussed by Stoker (1998), which presupposes a network of autonomous public and private institutions, in an environment in which there are unclear boundaries between public and private regarding the solution of problems that can only be solved with interdependent network action.
} 
the primary action comes from the area of Health. The involvement of other actors starts after the results of initial diagnosis and planning are provided by that specific area.

The disaster management cycle provides guidance on the steps that must be taken in each of the phases, including the initial ones that are sustained in specific areas. This cycle is the analytical framework most used in studies on tragedies, having migrated over the 20th century from a vision focused on responding, to one that busies itself with prevention and mitigation measures (Coetzee \& Niekerk, 2012). Both WHO and the National Civil Protection and Defense Policy (PNPDEC) use five phases to define the disaster cycle: prevention, mitigation, preparedness, response and recovery, as shown in Figure 1.

\section{FIGURE 1 THE DISASTER MANAGEMENT CYCLE}

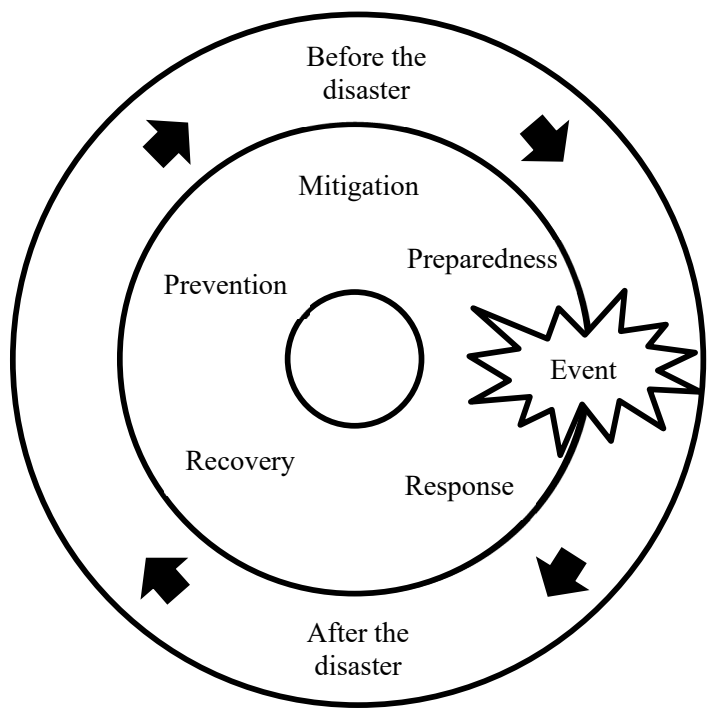

Source: Elaborated by the authors based on PNPDEC (2012) and Wisner and Adams (2002).

The prevention, mitigation and preparedness phases entail much of what is discussed in literature regarding disaster risk management (Matyas \& Pelling, 2014). Prevention focuses on permanent measures to avoid the occurrence of a disaster. These are taken by developing risk assessments and educational materials, as well as producing risk codes and zones. Mitigation, on the other hand, focuses more on creating resilience in structures and processes (Wisner \& Adams, 2002).

The preparedness phase consists of actions whose objective is to minimize the human and material losses of an imminent event, to enable the first responders' immediate availability and to organize the temporary removal of people. This may include drafting national plans and legislation for disaster management, forecasting international, national and sub-national levels of coordination and collaboration, training and strengthening staff and institutions who work with first responders, and educating the population, especially in areas most at risk of being affected (Wisner \& Adams, 2002).

The response, in turn, depends on all the previous phases, especially preparedness, which provides the basis for a prompt response. The following are the necessary conditions for an adequate response: 
availability of trained human resources, experienced leaders, adequate communication, access to transport and logistics, as well as action protocols for each type of emergency. Response actions can vary widely depending on the type of disaster. In the case of biological threats, the response time is different from that of natural and technological threats, for which the first 72 hours are decisive for the life-saving rescue of victims.

In the case of infestations, pests and epidemics, the response time depends on the State's ability to contain or control the dissemination of the biological agent; therefore, the response time is extended. Finally, the recovery phase - or, according to WHO, of rehabilitation, reconstruction and recovery consists of post emergency actions that aim the return to normality. Again, in the case of biological threats the recovery time is distinct and is directly proportional to the time required.

When evaluating the preparedness and response phases, there is a follow up assessment of the structure that precedes them - those of prevention and mitigation, which generated plans and legislation relevant to disasters. In addition, adequate preparedness is a necessary-but-not-sufficient condition for the response to be effective, which justifies the relevance of the mapping proposed in the present study.

Brazil is a signatory to the UN, and as such, is one of the 196 countries in which the International Health Regulations (RSI) have been in effect since 2007, when they were approved at the 58th WHO World Health Assembly. The text provides instructions for preventing and responding to a Public Health Emergency of International Importance (ESPII). According to the RSI, this emergency is characterized as "an extraordinary event which, under the terms of the present regulation, is determined as: (a) constituting a risk to public health for other States, due to the international dissemination of the disease and (b) potentially requiring a coordinated international response" (WHO, 2005, p. 9).

The RSI stipulates that countries are responsible for improving the means for detecting and evaluating events that occur in their territories, classifying them in emergencies of national or international importance, and they must communicate them to WHO when there is a risk of dissemination to other countries - exactly what China did with COVID-19. In addition, countries need to define the 'National Focal Points' (PFN) for the RSI. Among its attributions are the dissemination of information to the country's administrative sectors and the consolidation of the information that was sent, including the sectors responsible for surveillance and notification, points of entry, public health services, clinics, hospitals and other public departments (WHO, 2005).

The emphasis on the specialized response agencies - Health, in the case of this article - does not reduce the importance of actions aimed at disaster governance amid a plurality of other problems that arise from the same issue. This is due to the fact that there are many elements that alter the States' capacity for action in each of the phases, such as: the level of bureaucratic-institutional capacity of the responding entities, the level of urbanization, the coexistence of structural problems that increase the difficulty of the response, the level of centralization/decentralization of governmental decisions, the level and way in which citizens access information, the social capital of each region and the diversity of habits and ways of living (Ahrens \& Rudolph, 2006; Kiruthu, 2012; Quarantelli, Lagadec, \& Boin, 2007; Rumbach, 2016; Tierney, 2012).

Therefore, albeit not the primary objective of this article, pointers and roadmaps for governance will be analyzed, based on the study of the activation of the National Civil Protection and Defense System (SINPDEC) in the preparedness and response phases (see section 5). With that in mind, the next section explores how this activation is set out in the legislation. Next, it explores how it took place in the case of the COVID-19 pandemic. 


\section{THE STRUCTURE OF HEALTH DISASTERS MANAGEMENT IN BRAZIL}

This section describes the Brazilian structure organized by the National Civil Protection and Defense Policy (PNPDEC), which involves institutions such as the Ministry of health (MS), and institutes the National Civil Protection and Defense System (SINPDEC). This debate underlies the concept of disaster discussed in section 3 and its embodiment in the Brazilian legislation.

In accordance with the International Health Regulations (RSI) and Marco Sendai, the Brazilian legal framework, materialized in the Normative Instruction No. 2, 2016, and in the PNPDEC, supplies the definition and understanding of what is a Public Health Emergency (ESP), which at municipal and state levels, has two actions - emergency situation (SE) and state of public calamity (CP), subdivided into three hierarchical levels, according to the degree of intensity of the phenomenon. These are (1) an event that causes damages and losses that imply a partial impairment of the responsiveness of the Public Power towards the affected federative entity (SE), and (2) an event that affects the substantial impairment of the responsiveness of the Public Power towards the affected federative entity (CP).

Thus, the difference between SE and CP is the intensity and gravity of the damage caused, compared to the capacities of states and municipalities to deal with such damage (PNPDEC, 2017). As will be demonstrated in Box 1, the SE corresponds to levels I and II relative to the intensity of the event, while Level III corresponds to the CP. At the federal level, on the other hand, there is the Declaration of Public Health Emergency of National Importance (ESPIN), regulated by Decree No. 7,616, of 2011, and Ordinance No. 2,952, of the same year.

BOX 1

CLASSIFICATION, CHARACTERISTICS AND DISASTER ACTION10

\begin{tabular}{|c|c|c|}
\hline Level & Characteristics & Action \\
\hline $\begin{array}{l}\text { Level I (low } \\
\text { intensity) }\end{array}$ & $\begin{array}{l}\text { Only considerable human damage whose normality can be restored with } \\
\text { resources mobilized at the local level. }\end{array}$ & SE \\
\hline $\begin{array}{l}\text { Level II (medium } \\
\text { intensity) }\end{array}$ & $\begin{array}{l}\text { Damages and losses bearable and surmountable by local governments whose } \\
\text { normality can be restored with the resources mobilized at the local level or } \\
\text { complemented with the contribution of state and federal resources, affecting the } \\
\text { capacity of the local public power to respond to and manage the crisis installed. }\end{array}$ & SE \\
\hline $\begin{array}{l}\text { Level III (high } \\
\text { intensity) }\end{array}$ & $\begin{array}{l}\text { Damages and losses that cannot be overcome nor sustained by local } \\
\text { governments whose restoration of normality depends on the mobilization and } \\
\text { coordinated action of the three spheres of the SINPDEC activities and, in some } \\
\text { cases, international aid. }\end{array}$ & $\mathrm{CP}$ \\
\hline
\end{tabular}

Source: Adapted from PNPDEC (2017).

\footnotetext{
${ }^{10}$ The declaration of a CP and a SE at the state and municipal levels can occur concurrently with the existence of an ESPIN, since each of these occurrences provides for financial compensation or amortization of specific debts that need to be considered on a case-by-case basis. For a complete and updated list of states and municipalities actions of the CP or SEs, see the website of the Ministry of Regional Development. For the legislation that regulates the respective compensation for each of these actions, see Federal Law No. 12,340 (2010), Decree No. 5113 (2004), Decree No. 7,223 (2010), Decree No. 84,685 (1980), Law No. 12,983 (2014) and Decree-Law no. 3,365 (1941).
} 
It is clear that the delegation of responsibilities for each entity of the federation is based on the gravity of the disaster. Depending on the magnitude of the event, the coordination of the response with other entities may be necessary due to the exhaustion of the capacities deployed. Thus, disaster management in Brazil suggests a staggered mobilization of SINPDEC actors according to how the scenario evolves.

Law No. 12,608, of 2012, instituted the National Civil Protection and Defense System (SINPDEC). This legislation, updated in 2017, created the National Civil Protection and Defense Policy (PNPDEC). Until then, the document had been called the National Civil Defense Policy, and the protection dimension was only included in this latest version. The insertion of protection in the policy indicates an effort to emphasize the prevention and mitigation phases of the disaster management cycle, even though, as seen in the case of handling COVID-19, it has not materialized into actions. The SINPDEC, like the PNPDEC, is supported by a systemic approach, assigning an inter-agency aspect to disaster governance in Brazil.

ESPs - municipal, state or national - are subject to compulsory notification, controlled by the Center for Strategic Information on Health Surveillance (CIEVS), an agency subordinated to the Health Surveillance Secretariat (SVS) of the MS (Ordinance No. 30, 2005). The CIEVS is responsible for searching and gathering compulsory notifications and analyzing relevant data and information. It also tracks down, monitors and coordinates the response of the ESPs in conjunction with the state and municipal health departments. In addition, the CIEVS deals with crisis by organizing the monitoring of events that present a high potential for dissemination or risks to public health.

The 2016 National Focus Points (PFN) in the RSI operation plan says that the National SVS coordinates the preparation and response of health surveillance actions within the scope of the ESPIN and ESPII, with the CIEVS responsible for its operation. Within its actions, the plan provides for detecting ESPs and adopting appropriate measures, in addition to surveillance, prevention and control of communicable diseases, among other attributions (Brasil, 2016). In addition, it gives support to states and municipalities in situations of ESP.

The legal landmark for public health disaster governance in the PNPDEC is Law No. 8,080. In accordance with the PFN-RSI operation plan, "it instituted the Brazilian Universal Health System (SUS) as the single health administrator in each sphere of government (municipalities, states, Federal District and Union) and appointed the MS as its manager within the Union". The SUS has its own regulations on disaster risk management, established by the MS, setting out responsibilities, guidelines on implementation and funding of health surveillance actions, within the scope of the National Health Surveillance System and the National Sanitary Surveillance System (PNPDEC, 2017).

The Health sector preparedness and response to disasters guide, 2015 (Freitas, 2018), states that disaster preparedness begins long before it happens, through the elaboration and systematization of actions in the Preparedness Plan and Response (PPR). According to the PNPDEC, it is the responsibility of the National SVS to coordinate the preparedness and response of health surveillance actions regarding the ESPIN and ESPII. In order to do this, the National SVS establishes preparedness and response plans and elaborates specific contingency plans, which must be aligned with the Public Health Emergency Response Plan (PRESP), approved in 2014. The PRESP provides the guidelines for the National SVS to act in a timely, qualified and cooperative manner (Brasil, 2014; PNPDEC, 2017).

The PRESP systematizes the response to public health emergencies through steps to be taken according to a decision algorithm (Annex A - PRESP). Annex A contains the organized structures for dealing with the crisis. When the CIEVS notifies a rumor, a response is made by activating the Event Monitoring Committee (CME), whose objective is to monitor events of interest to the public health. If 
necessary, the decision-maker can choose to set up an Emergency Health Operations Center (COES), comprised of the general coordination and departments of the appropriate SVS, whose objective is to articulate and integrate the actors involved in the response (Brasil, 2014).

It is also worth highlighting some specific characteristics of the disaster caused by COVID-19. The occurrence of epidemics, especially of unknown diseases, can issue the ESPIN (PNPDEC, 2017). Unknown diseases, such as those caused by viruses of the beta coronavirus family, affect the response protocols, given that their epidemiological patterns - rate of dissemination, morbidity and type of contamination - are still undetermined. These characteristics affect the time of preparedness and response to the disaster (see section 3), since the event results from the exhaustion of the individual capacities of the federal entities. As will be discussed in section 5, despite being aware of the characteristics in the case of this pandemic, Brazil was one of the only countries in the world not to provide a nationally coordinated response to the disaster.

\section{FROM THE EMERGENCE OF THE DISEASE IN BRAZIL TO THE DISMISSAL OF MANDETTA}

This section explores the activation of the system presented in section 4 in a timeline that covers the period between the first cases of atypical pneumonia in China to the dismissal of former Minister Mandetta, as a mark of administrative discontinuity. Thus, we will seek to identify which actions were taken in the activation of the structures for disaster preparedness and response provided for in SINPDEC, as well as evidences of coordination between agencies.

Brazil has followed the evolution of the disease in China since December 12, 2019, through the Public Health Emergency Response Plan (PRESP), when it was still unclear whether the atypical pneumonias recorded in Wuhan were due to an unknown disease. On January 3, 2020, the Center for Strategic Information on Health Surveillance (CIEVS) requested a "rumor check" on the disease in China, the first step (preparedness phase) laid out in the PRESP that would activate the response to a health disaster. On January 10, the day after confirmation that it was a new virus, the Event Monitoring Committee (CME) was called on to monitor the outbreak of COVID-19 in the Asian country (PRESP, 2014).

Six days later, the National Health Surveillance Secretariat (SVS) published the first epidemiological bulletin with information on the new pneumonia (MS, 2020a). From then on, all the eventually confirmed cases of COVID-19 in Brazil would have to be reported to the CIEVS, in order to gather data about the epidemiology of the disease and its evolution in the country. Thus, January 3 marks the beginning of the operation of the health disaster management in Brazil regarding the preparedness phase (PNPDEC, 2017). On the 22nd of the same month, one day after the WHO statement regarding the moderate global risk of COVID-19, Brazil activated the Public Health Emergency Operations Center for the New Coronavirus (COE-nCoV), to alert level I (PRESP, 2014; Croda et al., 2020).

On January 27, Brazil announced the first suspected case of infection in the country, causing COE$\mathrm{nCoV}$ to change the national alert level from I to II (PRESP, 2014). On the same day, Ordinance No. 74 (National Health Surveillance Agency [Anvisa], 2020) established a Public Health Emergency Group to conduct the actions regarding the new coronavirus. On the 30th, the Interministerial Executive Group of Public Health Emergency of International Importance (GEI-ESPII) (see Decree $n^{\circ} 10.211$, of 2020), was created and, on February 3, the Ministry of Health (MS) instituted the Declaration of Public Health Emergency of National Importance (ESPIN) (see Ordinance $n^{\circ} 188$, of ${ }^{\circ} 2020$ ) and enforced the Decree $\mathrm{N}^{\circ} 7,616$, and Ordinance № 2,952, both of 2011. Consequently, the COE-nCoV raised the national alert 
level to III in accordance with PRESP (2014). On the same day, Decree No. 10,212 issued Article 4 in the International Health Regulations (RSI), indicating the activation of the Health Surveillance Secretariat/ Ministry of Health (SVS/MS) as the National Focus Point (PFN) in the RSI in Brazil. Its greatest mission would be to represent and notify WHO of events related to the pandemic.

What prompted the issuing of the ESPIN was the need to repatriate the Brazilians who were in Wuhan. Thus, on February 4, Law No. 13,979, of 2020, was passed, providing the guidelines on the quarantine period to which Brazilians repatriated from Wuhan would be subjected to when they arrived in Brazil.

The confirmation of the first case of COVID-19 in Brazil, on February 26, 2020, launched a new phase of the health disaster management cycle in the country. In response to this, on March 2, the MS launched the treatment protocol for the new coronavirus (MS, 2020b). Two days later, the Oswaldo Cruz Foundation (Fiocruz) started to distribute rapid testing kits (OMPV, 2020g), demonstrating the nation's watchful eye towards the international behavior of the virus.

As of February 29, when Brazil only had local transmission of the virus (OMPV, 2020f), a series of airspace restriction measures (OMPV, 2020f) and partial closure of national land borders (OMPV, 2020f) were adopted in an attempt to delay, albeit not able to prevent, the circulation of the virus throughout the national territory. Continuing with the implementation of the Brazilian disaster response structure, on March 16, the Federal Government established the Crisis Committee for Supervising and Monitoring the Impacts of COVID-19 to deal with the operational demands of the pandemic, such as the use of the National Public Security Funds, opening a public call for the acquisition of medical equipment considered strategic, and simplifying the process for declaring a Public Calamity (CP) in the national territory (Decree $\mathrm{n}^{\circ} 10.277$, of 2020). This Committee was initially not envisaged in the disaster governance, but it was established to manage the crisis within the scope of the Federal Government.

On March 20, Ordinance No. 454 (2020) declared the state of community transmission of COVID-19 in Brazil. On the same day, the Senate passed the Legislative Decree No. 6 (2020), which had been sent to Congress by the Presidency, which declared the state of $\mathrm{CP}$ throughout the national territory. The only national coordination action proposed by the Presidency up to that point. It is worth noting that the measure was not because of the Presidency's understanding of the need for nationally coordinated actions to tackle the pandemic; it was only taken to demonstrate their concern of incurring in actions that could be classified as a crime of responsibility - with the Decree, the Executive Branch was now allowed to spend more than what had been budgeted, and in so doing, circumvent the fiscal targets in order to fund actions to combat the pandemic.

One day after the CP was issued, the Joint Operations Center for the employment of the Armed Forces in combating COVID-19 was activated. Finally, on March 31, the then Minister of Justice, Sérgio Moro, authorized the use of the National Force to combat the pandemic in the country (OMPV, 2020i).

At the same time, on February 29, the same day that Brazil declared community transmission of the virus, in a statement on national television, the President minimized the possible impacts of COVID-19. This statement marked the beginning of the separation between the international recommendations and the views of the national technical bureaucracy, and what would become the Presidency's views regarding the gravity of the situation (OMPV, 2020g).

The escalation of the deterioration generated by this separation would also be reflected in the manifestations of mayors and governors in favor of the adequate treatment that the pandemic demanded, and in opposition to the stance taken by the Presidency (OMPV, 2020e; OMPV, 2020h). In the Executive Branch, however, disagreements over the most appropriate ways to manage the 
pandemic reached its peak with Mandetta's dismissal and his replacement by Nelson Teich, on April 17,2020 (OMPV, 2020j), resulting in an administrative discontinuity in the management of the crisis. To understand the sequence of events, Figure 2 shows the chronology of the pandemic preparedness and response phases.

\section{FIGURE 2 CHRONOLOGY OF PREPAREDNESS AND RESPONSE TO THE COVID-19 PANDEMIC IN BRAZIL}

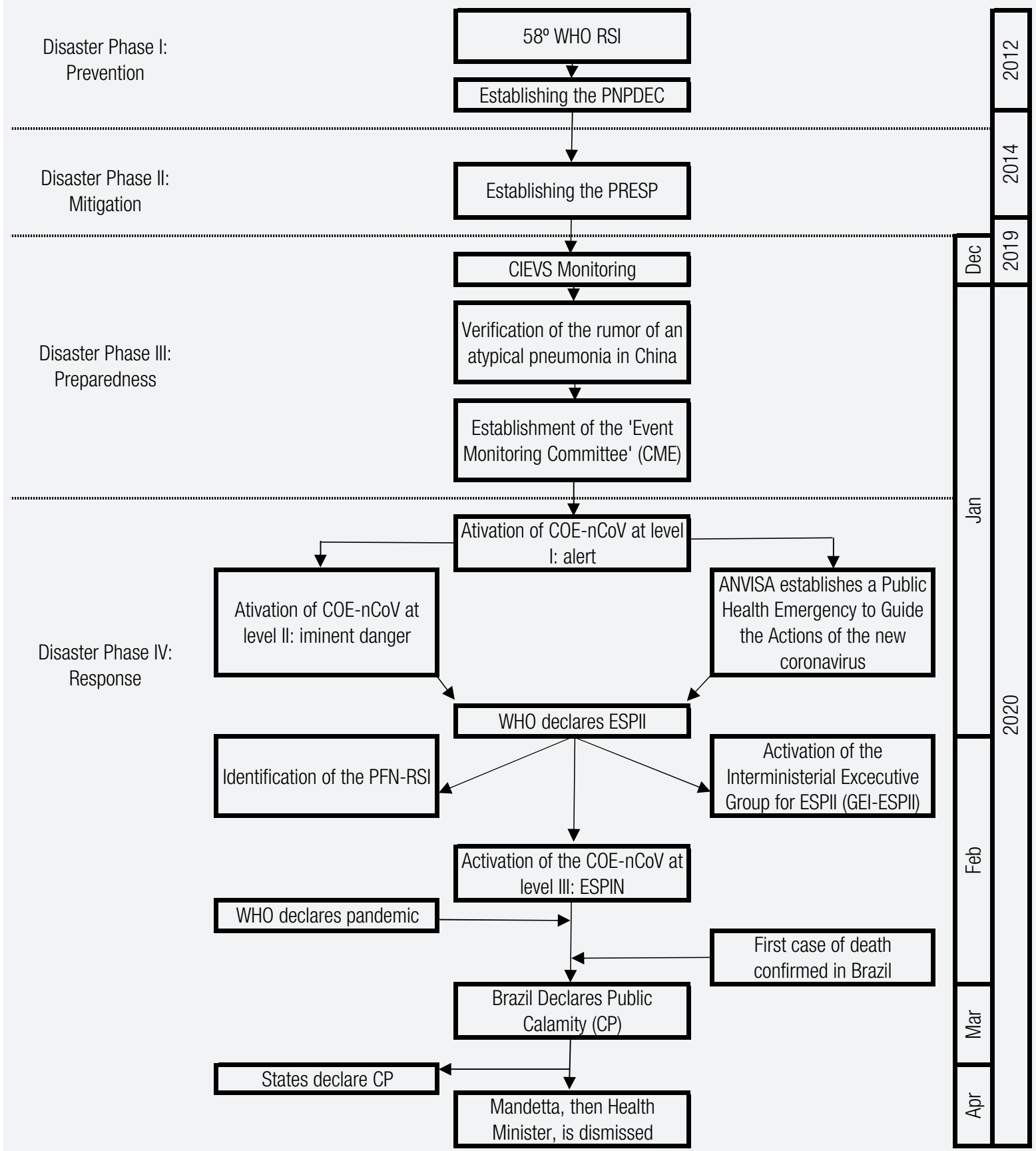

Source: Developed based on data from section 5 . 


\section{DESCRIPTIVE INFERENCES BASED ON THE CASE STUDY}

This section aims to retrieve the methodological arguments introduced in section 2 regarding the relevance of the method of descriptive inferences based on the chronological sequence of the phenomenon in question. Grounded on the concepts of the disaster cycle, the presentation of the Brazilian legal frameworks on disaster management and the chronology of the activation of the preparedness and response phases to COVID-19, this section offers some assertions stemming from the case. These assertions are not generalizable; they are only intended to serve as a guide for the future stages of this research agenda on disaster governance in Brazil. Therefore, they are proposed assertions according to the understanding of the empirical case and their scope is restricted to that case.

That aside, and considering what was set out in the previous sections, in an ESPII with strong social, economic and health impacts such as the COVID-19 pandemic, it is clear that disaster governance does not prevent the problem, but can manage it. Of course, this will depend on the mitigation of its impacts in the medium and long term, which can then provide a faster recovery in the post-crisis. Thus, the diagnoses provided from examining the Brazilian case sought to find a complex management, equal to an equally complex phenomenon. Nonetheless, what was uncovered was a situation aggravated by political decisions in an attempt to minimize the magnitude of the problem.

Since the first confirmed case of COVID-19 contamination in Brazil, a series of measures have been adopted by the SINPDEC, with the view of preparing the country to respond to the public health crisis resulting from the disease. Since the actions taken in the activation of the preparedness and response phases initially followed the WHO recommendations, the immediate response in Brazil shows an alignment between the national and international disaster governance structures. The concomitance between international recommendations and national decisions up to that point suggests that the evaluation from the specialized technical bureaucracy prevailed, in detriment of political readings of the situation at hand. From what is presented in sections 4 and 5, it is possible to conclude that Brazil has a robust legal framework with regard to tragedies and health disasters.

If disaster management structures were properly activated, why does the epidemiological curve in Brazil show such worrying results? At the time of writing this article, on July 2, 2020, the number of deaths recorded per day was 1,252, and the total number of deaths already exceeded 61,880 (COVID, 2020). Given the time limitation of the tests, the measures analyzed here referred to a still manageable context of records of contaminations and deaths. On the day that Mandetta was dismissed, there were 1,924 deaths and 30,425 infected (COVID, 2020). Therefore, the exponential growth of these numbers shows that the measures taken at the beginning of the crisis were insufficient.

Therefore, the answer seems be to that the legal robustness does not necessarily translate into implementation. In spite of that, Brazil is an experienced country with a vast history in combating epidemics, not only in the most recent cases such as dengue and the zika virus, chikungunya and yellow fever, but also in prevention campaigns, such as vaccination against influenza, measles and rubella, as well as in the treatment of serious infectious diseases, such as tuberculosis. In addition, the country has a public health system that, despite cuts in funding, is considered an example of universal care in the world (Gragnolati, Lindelow, \& Couttolenc, 2013). Through the Universal Health System (SUS), expensive and prolonged treatments, such as those for tuberculosis, syphilis, leprosy and 
leishmaniosis, are free for all Brazilians, as well as the supply of medicines for patients with chronic diseases, such as diabetics, cardiac and immunocompromised patients.

Although the MS followed international standards and recommendations in the preparation and initial response to the pandemic, a series of challenges in the sustained continuation of the response that had been outlined by the specialized bureaucracy, was quickly unveiled. The first challenge pertained to decision-making tensions on the proper way to control the contamination curve, in order to avoid the collapse of the public health system. An example of that can be found by retrieving successive presidential speeches that minimize the impacts of the disease and criticizes social isolation, under the cover of the need to maintain the national economy healthy (OMPV, 2020g).

Furthermore, by increasing the tone of the gravity of the pandemic in Brazil, the political impasse generated conflicts between the Presidency, on the one hand, and the Ministry of Health (MS) and state governments, on the other, with the last two adopting measures to flatten the contamination curve of COVID-19, regardless of the Presidency's views (OMPV, 2020g; OMPV, 2020h). The escalation of the pandemic management crisis headed by the Presidency led to the establishment of a 'Federal Government Joint Command', which, in practice, established a management structure to support the Presidency that resulted in emptying the decision-making power of the MS, reaffirming the administrative discontinuity represented by Mandetta's dismissal (Reuters, 2020).

The political and decision-making tensions arising from the positioning of the Presidency, at first, did not impact the work of the specialized health bureaucracy and inter-ministerial coordination, so there was no paralyzing decision affecting the public machinery, demonstrated by the development of inter-ministerial committees and centers, the daily press conferences of Minister Mandetta and the activation of the coordination within the scope of the PRESP and COE-nCoV, among others.

Nevertheless, while the diagnosis offered here supports the thesis that the technical understanding of the activation of the preparedness and response phases to COVID-19 prevailed, it is important to consider that this scenario has suffered the consequences of the (non) made decisions in the prevention and mitigation phases. Emphasizing the aforementioned fact that health treatment is not a strategic area in Brazil, the nation faced severe challenges in obtaining testing kits, materials and supplies necessary for RT-PCR tests, as well as simple items for individual protection equipment (IPEs) and other more complex ones, such as the respirators on which critically ill patients depended (Barifouse, 2020).

The lack of human resources generated a rush for emergency courses and an ad hoc call for professionals from all health segments: dentists, veterinarians, physiotherapists and physical educators (Barifouse, 2020; Ordinance No. 639, 2020; Operation COVID-19, 2020). As mentioned before, these difficulties confirm the flaws in the phases of prevention and mitigation of the disaster cycle, with considerable room for improvement.

From the study of the Brazilian case, it appears that, despite the country's experience in handling public health crises, neglect in the prevention and mitigation phases became barriers in carrying out the preparedness and response to the event, jeopardizing the structure of the entire cycle of disasters. Conversely, if Brazil had implemented the guidelines of the 58th World Health Assembly and Marco Sendai, as well as treated the health area from a strategic perspective, it would have been able to manage the preparedness and response phases as the problem required, however complex. Likewise, 
the politicization of disaster management has aggravated the already fragile disaster management structure, resulting in worsening rather than in overcoming the phenomenon. Finally, the strength of the bureaucratic isolation of specialized institutions, such as the "islands of rationality and technical specialization" (Nunes, 2017), protected from political willfulness, was challenged by the pandemic, and only resisted the prolonged friction with the Presidency to a certain extent. As a result, it is necessary to reflect on the need to create other mechanisms that shield specialized areas, especially in the case of disasters that affect the lives of all citizens.

\section{FINAL CONSIDERATIONS}

As a general objective, this article questions how the public health crisis caused by the COVID-19 pandemic helped to understand the work of the National System of Civil Defense and Protection (SINPDEC) in the phases of preparedness and response to health disasters in Brazil, with an emphasis on the role of the Ministry of Health (MS), defined as the management body in the fight against health threats. The study was limited to the period that started with the first rumors of atypical pneumonia in China, verified by the Ministry of Health, ending with the dismissal of Luiz Henrique Mandetta. The operationalization of the general objective was determined by the characterization of COVID-19 as a public health event with potential to cause disaster. It also verifies the existence of the concepts of preparedness and response in the disaster governance literature, as well as what that section entailed, the identification of legal provisions and the work of disaster management in Brazil, described in sections 4 and 5, respectively. The process tracing variant of descriptive inferences, presented in section 2, was used as a methodological support to guide research between the empirical and theoretical-conceptual universes.

Despite the political decision-making tensions, the Brazilian professional bureaucracy managed to guarantee the activation of the system regarding the preparedness and response phases in the National Civil Protection and Defense System (SINPDEC). However, as expressed by the 4 assertions in section 6 , this article concludes that the country's weakness in health is structural. This conclusion comes as a result of health treatment not being a strategic area in Brazil, which jeopardized the entire cycle of disaster management in dealing with COVID-19, deteriorating the situation identified in the response phase. Thus, the bureaucratic isolation of specialized structures in health and disasters, which could only resist the pressure to minimize the gravity of the crisis to some extent, took its toll. The dismissal of Mandetta and the consequent discontinuity of the leadership of the MS has led to this realization.

This article was conceived as part of a research agenda that aims to debate these and other points concerning governance and the disaster management cycle in Brazil. The understanding of the issue, specifically in the case of COVID-19, still needs future researches that will contemplate: a methodological discussion, now using the causal variants of process tracing; an analysis of the recovery phase of the post-COVID-19 crisis management; the coordination between the federal and state levels of response; the systemic approach proposed in the National Civil Protection and Defense Policy (PNPDEC) and the practical difficulties that this entails in managing a crisis; the limits of government transparency during the phases of the disaster; disaster risk analysis versus preparedness of responders; and, finally, the debate between health disasters, zoonoses and the concept of One Health proposed by WHO. 


\section{REFERENCES}

Ahrens, J., \& Rudolph, P. M. (2006). The importance of governance in risk reduction and disaster management. Journal of Contingencies and Crisis Management, 14(4), 207-220.

Barifouse, R. (2020, March 09). Brasil não adota novo critério da OMS que amplia busca por casos suspeitos. Época. Retrieved from https://epoca. globo.com/brasil/coronavirus-brasil-nao-adotanovo-criterio-da-oms-que-amplia-busca-por-casossuspeitos-24294775

Beach, D. (2016). It's all about mechanisms-what process-tracing case studies should be tracing. New Political Economy, 21(5), 463-472.

Beach, D., \& Pedersen, R. B. (2019). Process-tracing methods: Foundations and guidelines. Ann Arbor, Michigan: University of Michigan Press.

Bennett, A. (2015). Using process tracing to improve policy making: The (negative) case of the 2003 intervention in Iraq. Security Studies, 24(2), 228-238.

Bennett, A., \& George, A. L. (1997). Process tracing in case study research. Washington, DC: MacArthur Program on Case Studies.

Casa Civil. (2017). Manual de Proteção e Defesa Civil: A Política Nacional de Proteção e Defesa Civil. Brasília, DF: Ministério da Integração Nacional.

Centro Universitário de Estudos e Pesquisas sobre Desastres. (2012). Política Nacional de Defesa Civil. Florianópolis, SC: Universidade Federal de Santa Catarina.

Checkel, J. T. (2006). Tracing causal mechanisms. International Studies Review, 8(2), 362-370.

Coetzee, C., \& Van Niekerk, D. (2012). Tracking the evolution of the disaster management cycle: a general system theory approach. Jàmbá: Journal of Disaster Risk Studies, 4(1), 1-9.

Collier, D. (2011). Teaching process tracing: exercises and examples. PS: Political Science and Politics, 44(4), 823-830.

Croda et al. (2020). COVID-19 in Brazil: advantages of a socialized unified health system and preparation to contain cases. Journal of the Brazilian Society of Tropical Medicine, 53, e20200167.
Decreto Legislativo $n^{\circ}$ 6, de 20 de março de 2020. (2020). Reconhece, para os fins do art. 65 da Lei Complementar $n^{\circ} 101$, de 4 de maio de 2000, a ocorrência do estado de calamidade pública, nos termos da solicitação do presidente da República encaminhada por meio da mensagem no 93, de 18 de março de 2020. Brasília, DF: Presidência da República.

Decreto $n^{\circ} 10.211$, de 30 de janeiro de 2020. (2020). Dispõe sobre o Grupo Executivo Interministerial de Emergência em Saúde Pública de Importância Nacional e Internacional (GEI-ESPII). Brasília, DF: Presidência da República.

Decreto $n^{\circ} 10.212$, de 30 de janeiro de 2020. (2020). Promulga o texto revisado do Regulamento Sanitário Internacional, acordado na 58 a Assembleia Geral da Organização Mundial de Saúde, em 23 de maio de 2005. Brasília, DF: Presidência da República.

Decreto $n^{\circ}$ 10.277, de 16 de março de 2020. (2020). Institui o Comitê de Crise para Supervisão e Monitoramento dos Impactos da COVID-19. Brasília, DF: Presidência da República.

Decreto $n^{\circ} 7.616$, de 17 de novembro de 2011. (2011). Dispõe sobre a declaração de Emergência em Saúde Pública de Importância Nacional (ESPIN) e institui a Força Nacional do Sistema Único de Saúde (FNSUS). Brasília, DF: Presidência da República.

Dhiman, C, R., Tiwari, A. (2018). Emergence of Zoonotic Diseases in India: A Systematic Review. Medical Reports \& Case Studies, 3(3), 1-8.

Do, X. B. (2019, June). Return migration after the Fukushima Daiichi nuclear disaster: the impact of institutional and individual factors. Disasters, 44(3):569-595.

Enserink, M. (2004). Looking the Pandemic in the Eye. Science, 306(5695), 392-394.

Etinay, N., Egbu, C., \& Murray, V. (2018). Building Urban Resilience for Disaster Risk Management and Disaster Risk Reduction. Procedia Engineering, 212(2017), 575-582.

Freitas, C. M. (2018). Guia de preparação e respostas do setor saúde aos desastres. Rio de Janeiro, RJ: Fiocruz, Secretaria de Vigilância em Saúde.

George, A. L., Bennett, A., Lynn-Jones, S. M., \& Miller, S. E. (2005). Case studies and theory 
development in the social sciences. Cambridge, MA: MIT Press.

Gragnolati, M., Lindelow, M., \& Couttolenc, B. (2013). Twenty Years of Health System Reform in Brazil: An Assessment of the Sistema Único de Saúde. Directions in Development--Human Development. Washington, DC: World Bank.

Instrução Normativa n 2, de 20 de dezembro de 2016. (2016). Estabelece procedimentos e critérios para a decretação de situação de emergência ou estado de calamidade pública pelos Municípios, Estados e pelo Distrito Federal, e para o reconhecimento federal das situações de anormalidade decretadas pelos entes federativos e dá outras providências. Brasília, DF: Ministério da Integração Nacional.

Kiruthu, F. (2014). Book Review: Building Resilience: Social Capital in Post Disaster Recovery. Daniel P. Aldrich. University of Chicago Press, 2012. Governance, 1, 169-171.

Kooiman, J. (1999). Social-Political Governance. Public Management: An International Journal of Research and Theory, 1(1), 67-92.

Lei 12.608, de 10 de abril de 2012. (2012). Institui a Política Nacional de Proteção e Defesa Civil (PNPDEC); dispõe sobre o Sistema Nacional de Proteção e Defesa Civil (SINPDEC) e o Conselho Nacional de Proteção e Defesa Civil (Conpdec); autoriza a criação de sistema de informações e monitoramento de desastres; altera as Leis $n^{\circ} 12.340$, de $1^{\circ}$ de dezembro de 2010, 10.257, de 10 de julho de 2001, 6.766, de 19 de dezembro de 1979, 8.239, de 4 de outubro de 1991, e 9.394, de 20 de dezembro de 1996; e dá outras providências. Brasília, DF.

Lei $n^{\circ} 12.340$, de $1^{\circ}$ de dezembro de 2010. (2010). Dispõe sobre as transferências de recursos da União aos órgãos e entidades dos Estados, Distrito Federal e Municípios para a execução de ações de prevenção em áreas de risco de desastres e de resposta e de recuperação em áreas atingidas por desastres e sobre o Fundo Nacional para Calamidades Públicas, Proteção e Defesa Civil; e dá outras providências. Brasília, DF: Presidência da República.

Lei $n^{\circ}$ 13.979, de 6 de fevereiro de 2020. (2020). Dispõe sobre as medidas para enfrentamento da emergência de saúde pública de importância internacional decorrente do coronavírus responsável pelo surto de 2019. Diário Oficial da União: seção
1, Brasília, DF: Agência Nacional de Vigilância Epidemiológica.

Lima, Y, Costa, E. (2014). Regulamento sanitário internacional: emergências em saúde pública, medidas restritivas de liberdade e liberdades individuais. Vig Sanit Debate, 3(1),10-18.

Mahoney, J. (2015). Process tracing and historical explanation. Security Studies, 24(2), 200-218.

Matyas, David; Pelling, Mark. (2014). Positioning resilience for 2015: the role of resistance, incremental adjustment and transformation in disaster risk management policy. Disasters, 39(s1), 1-19.

Ministério da Saúde. (2014). Plano de Respostas às Emergências em Saúde Pública. Brasília, DF: Author.

Ministério da Saúde. (2018). Guia para Investigações de Surtos ou Epidemias. Brasília, DF: Author. Retrieved from https://www.saude.gov.br/images/ pdf/2018/novembro/21/guia-investigacao-surtosepidemias-web.pdf

Ministério da Saúde. (2020a). Boletim Epidemiológico. Situação epidemiológica da febre amarela no monitoramento 2019/2020. Brasília, DF: Secretaria de Vigilância Epidemiológica.

Ministério da Saúde. (2020b). Protocolo de Tratamento do Novo Coronavírus (2019-nCoV). Brasília, DF: Author.

Ministério da Saúde. (2020c, April 30). Painel Coronavírus. Brasília, DF: Author. Retrieved from https://covid.saude.gov.br/

Nunes, E. O. (2017). A gramática política do Brasil: clientelismo, corporativismo e insulamento burocrático. (5. Ed.). Rio de Janeiro, RJ: Garamond.

Observatório Militar da Praia Vermelha. (2020). DQBRN e Precursores - Clipagem de Notícias. Rio de Janeiro, RJ: Author. Retrieved from http://ompv. eceme.eb.mil.br/masterpage_assunto.php?id=210

Observatório Militar da Praia Vermelha. (2020a). $D Q B R N$ e Precursores - Clipagem de Notícias Semana 1. Rio de Janeiro, RJ: Author. Retrieved from http://ompv.eceme.eb.mil.br/docs/dqbrn/ SEM01_31_12ate05_01.pdf

Observatório Militar da Praia Vermelha. (2020b). $D Q B R N$ e Precursores - Clipagem de Notícias Semana 2. Rio de Janeiro, RJ: Author. Retrieved 
from http://ompv.eceme.eb.mil.br/docs/dqbrn/ SEM02_06_01ate12_01.pdf

Observatório Militar da Praia Vermelha. (2020c). $D Q B R N$ e Precursores - Clipagem de Notícias Semana 3. Rio de Janeiro, RJ: Author. Retrieved from http://ompv.eceme.eb.mil.br/docs/dqbrn/ SEM03_13_01ate19_01.pdf

Observatório Militar da Praia Vermelha. (2020d). $D Q B R N$ e Precursores - Clipagem de Notícias Semana 5. Rio de Janeiro, RJ: Author. Retrieved from http://ompv.eceme.eb.mil.br/docs/dqbrn/ SEM05_27_01ate02_02.pdf

Observatório Militar da Praia Vermelha. (2020e). $D Q B R N$ e Precursores - Clipagem de Notícias Semana 11. Rio de Janeiro, RJ: Author. Retrieved from http://ompv.eceme.eb.mil.br/docs/dqbrn/ SEM11_09_03ate15_03.pdf

Observatório Militar da Praia Vermelha. (2020f). $D Q B R N$ e Precursores - Clipagem de Notícias Semana 9. Rio de Janeiro, RJ: Author. Retrieved from http://ompv.eceme.eb.mil.br/docs/dqbrn/ SEM09_24_02ate01_03.pdf

Observatório Militar da Praia Vermelha. (2020g). $D Q B R N$ e Precursores - Clipagem de Notícias Semana 10. Rio de Janeiro, RJ: Author. Retrieved from http://ompv.eceme.eb.mil.br/docs/dqbrn/ SEM10_02_03ate08_03.pdf

Observatório Militar da Praia Vermelha. (2020h). $D Q B R N$ e Precursores - Clipagem de Notícias Semana 12. Rio de Janeiro, RJ: Author. Retrieved from http://ompv.eceme.eb.mil.br/docs/dqbrn/ SEM12_16_03ate22_03.pdf

Observatório Militar da Praia Vermelha. (2020i). $D Q B R N$ e Precursores - Clipagem de Notícias Semana 14. Rio de Janeiro, RJ: Author. Retrieved from http://ompv.eceme.eb.mil.br/docs/dqbrn/ SEM14_30_03ate05_04.pdf

Observatório Militar da Praia Vermelha. (2020j). $D Q B R N$ e Precursores - Clipagem de Notícias Semana 16. Rio de Janeiro, RJ: Author. Retrieved from http://ompv.eceme.eb.mil.br/docs/dqbrn/ SEM16_13_04ate19_04.pdf

Operação COVID-19. (2020, March 30). Militares realizam treinamento em defesa nuclear, biológica, química e radiológica para operação COVID-19.
Retrieved from https://operacaocovid19.defesa. gov.br/noticias/noticia/770-militares-realizamtreinamento-em-defesa-nuclear-biologica-quimicae-radiologica-para-operacao-covid-19

Organização Mundial da Saúde. (2005). International Health Regulations (2nd. Ed.). Geneva, Switzerland: Author. Retrieved from http://portal.anvisa.gov.br/ documents/375992/4011173/9789241580410_eng. pdf/36b8b474-c10f-4433-82d4-18a04bc5a736

Organização Mundial da Saúde. (2011, May). Disaster Risk Management for Health: overview. Geneva, Switzerland: Author. Retrieved from https://www. who.int/hac/events/drm_fact_sheet_overview.pdf

Organização Mundial da Saúde. (2020a, February 21). Coronavirus disease 2019 (COVID-19) (Situation Report, 32). Geneva, Switzerland: Author. Retrieved from https://www.who.int/docs/default-source/ coronaviruse/situation-reports/20200221-sitrep-32COVID-19.pdf?sfvrsn=4802d089_2

Tannenwald, N. (1999). The nuclear taboo: The United States and the normative basis of nuclear non-use. International organization, 53(3), 433-468.

Portaria ANVISA no 74, de 27 de janeiro de 2020. (2020). Dispõe sobre a criação de Grupo de Emergência em Saúde Pública para condução das ações referentes ao Novo Coronavírus ( $\mathrm{NCoV}$ ). Brasília, DF: Ministério da Saúde.

Portaria $n^{\circ} 2.952$, de 14 de dezembro de 2011. (2011). Regulamenta, no âmbito do Sistema Único de Saúde (SUS), o Decreto $\mathrm{n}^{\circ}$ 7.616, de 17 de novembro de 2011, que dispõe sobre a declaração de Emergência em Saúde Pública de Importância Nacional (ESPIN) e institui a Força Nacional do Sistema Único de Saúde (FN-SUS). Brasília, DF: Ministério da Saúde.

Portaria $n^{\circ}$ 30, de 7 de julho de 2005. (2005). Institui o Centro de Informações Estratégicas em Vigilância em Saúde, define suas atribuições, composição e coordenação. Brasília, DF: Ministério da Saúde.

Portaria $n^{\circ} 454$, de 20 de março de 2020. (2020). Declara, em todo território nacional, o estado de transmissão comunitária do coronavírus (COVID-19). Brasília, DF: Ministério da Saúde.

Portaria $n^{\circ}$ 639, de 31 de março de 2020. (2020). Dispõe sobre a Ação Estratégica "O Brasil Conta Comigo - Profissionais da Saúde", voltada à capacitação e ao cadastramento de profissionais da 
área de saúde, para o enfrentamento à pandemia do coronavírus (COVID-19). Brasília, DF: Ministério da Saúde.

Portaria $n^{\circ} 188$, de 3 de fevereiro de 2020. (2020). Declara Emergência em Saúde Pública de importância Nacional (ESPIN) em decorrência da Infecção Humana pelo novo Coronavírus (2019nCoV). Brasília, DF.

Programa das Nações Unidas para o Desenvolvimento. (2020). Gestão de Riscos e Desastres Naturais. Brasília, DF: Author. Retrieved from https://www. br.undp.org/content/brazil/pt/home/projects/riscoe-desastres.html

Programa das Nações Unidas para o Meio Ambiente. (2020, March 03). Coronavirus outbreak highlights need to address threats to ecosystems and wildlife. Retrieved from https://www.unenvironment.org/news-andstories/story/coronavirus-outbreak-highlights-needaddress-threats-ecosystems-and-wildlife

Quarantelli, E. L., Lagadec, P., \& Boin, A. (2007). A heuristic approach to future disasters and crises: new, old, and in-between types. In H. Rodriguez, E. L. Quarantelli, R. Dynes (Eds.), Handbook of disaster research (pp. 16-41). New York, NY: Springer.

Resolução no 588, de 12 de julho de 2018. (2018). Fica instituída a Política Nacional de Vigilância em Saúde (PNVS), aprovada por meio desta resolução. Brasília, DF: Conselho Nacional de Secretarias Municipais de Saúde.

Reuters. (2020, May 26). Special Report: Bolsonaro brought in his generals to fight coronavirus. Brazil is losing the battle. Retrieved from https://www.reuters. com/article/us-health-coronavirus-brazil-responsesp-idUSKBN2321DU
Rumbach, A. (2016). Decentralization and small cities: Towards more effective urban disaster governance? Habitat International, 52(2015), 35-42.

Sabatier, P. A. (Ed.). (2007). Theories of the Policy Process. Boulder, Colorado: Westview Press.

Secretaria Nacional de Defesa Civil. (2007). Política Nacional de Defesa Civil. Brasília, DF: Ministério da Integração Nacional.

Stoker, G. (1998). Governance as theory: five propositions. International Social Science Journal, $50,17-28$.

Tierney, K. (2012). Disaster Governance: Social, Political, and Economic Dimensions. Annual Review of Environment and Resources, 37(1), 341-363.

Wisner, B, Adams, J. (2002). Environmental health in emergencies and disasters: a practical guide. Geneva, Switzerland: World Health Organization. Retrieved from https://apps.who.int/iris/handle/10665/42561

United Nations Office for Disaster Risk Reduction. (2009). 2009 UNISDR terminology on disaster risk reduction. Retrieved from https://www.undrr.org/ publication/2009-unisdr-terminology-disaster-riskreduction

United Nations Office for Disaster Risk Reduction. (2015). Marco de Sendai para la Reducción del Riesgo de Desastres 2015-2030. Retrieved from https://www.preventionweb.net/files/43291_ spanishsendaiframeworkfordisasterri.pdf

Zurita, M. de L. M., Cook, B., Harms, L., \& March, A. (2015). Towards New Disaster Governance: Subsidiarity as a Critical Tool. Environmental Policy and Governance, 25(6), 386-398. 


\section{Karina Furtado Rodrigues}

https://orcid.org/0000-0001-9330-6399

Ph.D. in Administration from the Brazilian School of Public Administration and Business of the Getulio Vargas Foundation (FGV EBAPE); Professor of the Post-Graduate Program in Military Sciences (PPGCM) at the Meira Mattos Institute, in the Brazilian Army Command and General Staff College (IMM/ECEME). E-mail: karinafrodrigues@gmail.com

\section{Mariana Montez Carpes}

https://orcid.org/0000-0002-7581-2973

Ph.D. in International Relations from the University of Hamburg; Professor of the Post-Graduate Program in Military Sciences (PPGCM) at the Meira Mattos Institute, in the Brazilian Army Command and General Staff College (IMM/ECEME). E-mail: mariana.montez.carpes@gmail.com

\section{Carolina Gomes Raffagnato}

https://orcid.org/0000-0001-7426-3864

Bachelor Degree in Chemical Engineering from the Federal University of Rio de Janeiro; M.A. Student of the Post-Graduate Program in Military Sciences (PPGCM) at the Meira Mattos Institute, in the Brazilian Army Command and General Staff College (IMM/ECEME). E-mail: carolina.raffagnato@gmail.com 